\title{
Voter Registration Cards, Political Subjectivity, and Trust in Paper in the Gambia
}

\author{
NIKLAS HULTIN
}

\begin{abstract}
This article examines the voter registration card and the social context of voter registrations in the Gambia, West Africa. Drawing on recent ethnographies of documents and using data on worries over foreigners' efforts to fraudulently obtain voter registration cards, a public information campaign on the Gambian electoral process, international legal material on the Gambian democracy, and observations at voter registration stations, the article argues that the voter registration card delineates not only a national subject but also a generic political subject. This subject is characterized by a commitment to a bureaucratic process and an appreciation of the card as an official identification document inseparable from the person it identifies. The article also considers how the voter registration process allows Gambians to compare their experiences to citizens of other countries. In a political context of an authoritarian government and a weak rule of law, this comparison offers an ideal of a modern democratic state that both enables criticism of the Gambia's present situation and confirms the centrality of a generic political subject to the realization of that ideal.
\end{abstract}

* Key words elections, the state, bureaucracy, ideals, the Gambia

\section{Introduction}

A Gambian voter registration card is a laminated piece of paper roughly the size of a US or EU driver license. This paper is an iconic representation of the Gambian flag. It has three broad horizontal stripes - red, blue, and green with thin white lines separating the red stripe from the blue stripe and the blue stripe from the green stripe. On the front of the card is the national coat of arms, the serial number of the card, a photograph of the holder, and the 
following information: the holder's surname, first name, home village or town, street address, occupation, and polling station. On the back of the card are two big squares. In the left square is the signature or thumbprint of the holder and in the right square is the date stamp and initials of the Independent Electoral Commission (IEC) official who oversaw the registration process during which the card was obtained. Above these two squares is the following text. "This card is issued to the person named herein and must be produced by the said person when casting a vote at an election in which he is qualified to vote. It is of no value to any other person and, if found, must be returned to [the local office of IEC, identified with a sticker]". In the upper left corner of the back of the card is the logo of the IEC: a hand holding a red marble reaching toward a drum-shaped ballot box. ${ }^{1}$

In this article, I argue that although the card is an identity document, it is more than a materialization of a technocratic modality of rule serving to embrace subjects and rendering this embrace verifiable and quantifiable (cf. Torpey 2000). Yngvesson and Coutin (2006), among others, have argued that identity documents are semiotic indices pointing to a quality in the item's holder and, thus, having the ability to establish and close-off lawful residence and national belonging. Drawing on this insight, I argue that the political significance of documents is more than their capability to index a membership in a nation. Their significance also lies in the social valuation of an audience's recognition of this indexing in the first place. In other words, the apprehension of the semiotic relationship between identity documents and individuals, a self-identification with documents (Derrida 2005:56), itself indexes a particular political subjectivity. This subjectivity is not that of a Gambian citizen in contradistinction to a non-Gambian. Rather, the card draws a distinction between persons who correctly understand that the card is an on-paper extension of the self and who value the processes surrounding the card, such as its procurement through voter registration from those persons who fail to grasp this extension. This subjectivity is thus marked not by national belonging but by the proper concern with formal bureaucratic processes which are putatively generic rather than insolubly Gambian (cf. Stinchcombe 2001:55).

By attending to the voter registration card, this article also considers how the state is imagined in the Gambia. Anthropologists and others have come to view the state as existing not independently of social relations and as manifested in encounters with institutions, symbols, and practices (e.g. Ferguson and Gupta 2002, Mitchell 1991). How such manifestations take place in Africa and whether or not African states can be considered simply as instantiations of a global state form is more of an open question, however (Chalfin 2006, Ferguson 2005, West 2003). Rather than suggesting that the African state, in some essential fashion, is one thing or another, I argue that the Gambian voter registration card is a way for political subjects to render the 
Gambian state commensurable to other states and, in effect, that it enables them to consider the Gambian state as an instantiation of a global form. Building on Thomas Osborne's claim that documentary practices form part of a state's ethical competence to rule (1994: 290, cited in Riles 2006b: 5), I suggest that the "proper" apprehension of documentation serves as a way both for citizens to assess their states and for states to be rendered commensurable against yardsticks such as those provided by the international language of human rights and free and fair elections. Voter registration cards accordingly offer a vehicle to imagine an ideal and to substantiate criticisms of the absence of this ideal. ${ }^{2}$ The political subjectivity I argue for herein is hence not only a subjectivity in the present but also one implying a relation between the present and the axiomatic, the is and the ought to be. Thus, the function of the voter registration card in the Gambia is fundamentally "prospective," a way to promote an ideal and to ensure a measure of trust and predictability in the tumult of life (Miyazaki 2006: 120, cf. Sztompka 1999: 18-19, Weiss 2002).

My argument builds upon recent work in the anthropology of documents and other technocratic practices that seeks to move beyond an essentially Foucauldian frame of analysis (e.g. Gordillo 2006, Riles 2001, Riles 2006a, Yngvesson and Coutin 2006, see also Silverstein and Urban 1996). In this Foucauldian frame, bureaucratic knowledge practices (documentation, calculation, verification, etc.) are examined as strategies of rule that derive their power from their ability to constitute and classify groups, render social phenomena legible, and establish or foreclose social relations (see, for example, Foucault 1991, 1995). Following Reed (2006) and others, I consider that this approach risks downplaying the social significance of official documents beyond their denotational and classificatory function. In a study of prison documents in Papua New Guinea, for example, Reed argues that the Foucauldian "normative" perspective insufficiently illuminates the "nonstrategic status" (2006:163) of official documents. What is thus less clear is not the way they render subjects to be politically controlled but rather the way they possess "qualities of replication and self-extension" (2006:172) through which new potential relations and statuses emerge. The caesura opened up by Reed is a minor but important one. I draw on this caesura for a broader analytical view of the card beyond the overt and denotational subjectivity manifested in the document, and I consider the potentialities of being and belonging that are visible when considering documents in their broader cultural and institutional context. ${ }^{3}$

Using the Gambian voter registration card as a case study, I develop the argument that the subjectivity inherent in the card is that of a generic political subject. This subject properly apprehends the card's ability to index and values the processes and interactions surrounding the card, such as its procurement through registration and its use in the voting process. The article 
first looks at the voter registration process as described by newspaper reports and IEC officials to show how a normative analysis (in Reed's sense) of voter registration cards begins to fray. I use the notion of beleaguerment to describe an anxiety over the influence of others that is exacerbated by the perceived inadequacy of bureaucratic procedures. This notion underlines the inextricability of the card's meaning from the process of procurement. Second, I focus on the material card itself and a public awareness campaign informing Gambians of the proper care of the card - that the card should not be sold, for example - to discuss the card's wider semiotic context and the relation between the card and its holder, a relation which goes beyond the card's capacity to index the national belonging of the holder. Finally, I consider how the card and the processes around it allow for a commensuration of state practices in spite of the cards having their own peculiar, nation-bound, histories - an assessment that, in turn, reverts back to the constitution of a generic political subject and, in a sense, confirms it. In this section, I rely on data on the voter registration process and I also consider the international assessment of the Gambia's voter registration process in the form of an international report and a legal case.

\section{Mr. Joof's Lament: Beleaguerment and the Understanding of Procedure}

I conducted research in the Gambia's capital, Banjul, and its immediate surroundings in 2003 and 2004. I examined the role of human rights organizations in the Gambia and most of the Gambians with whom I had extended interactions were thought of as middle class. They included lawyers, journalists, NGO workers, businesspersons, and government civil servants. Many of these individuals were anxious about the Gambia's future under the present government, led by President Yahya Jammeh who seized power in a military coup in 1994. Jammeh won presidential elections in 1997, 2001, and 2006 that were domestically disputed but were considered reasonably free and fair by international observers (see, for instance, Commonwealth Observer Group 2002). This international validation aside, Jammeh's rule has been characterized by significant human rights concerns. In 2004, one senior journalist and outspoken critic of the government was killed under mysterious circumstances and other journalists have fled the country. The security services have been accused of political violence and intimidation. One man, to whom I was introduced by an opposition politician, showed me lacerations he said were due to police beatings after he was caught celebrating the political opposition's win in a by-election. Both men insisted such incidents were widespread. I also heard reports of several substantively different versions of the constitution printed and circulated by the 
government during the period of my research. When I visited the government printer to examine these reports I was told that the constitution was out of print and that there were no specific plans to print it again-a response that illustrates the Gambia's precarious rule of law. ${ }^{4}$

Against this backdrop the Gambia's voter registration process became front page news. In April, 2004, Gambian newspapers reported that nationals of the Casamance region of neighboring Senegal had stormed a temporary office of the IEC established for the conduct of a supplementary registration drive. ${ }^{5}$ The Senegalese demanded to be registered to vote. As they did not have any of the required identification documents - a passport, a national identity card, a birth certificate, or a letter of attestation from five elders of the community, the village chief (alkalo), or district chief (seyfo), an IEC official turned them away. The official later justified his rejection to one newspaper: "Once these non-Gambians succeed in their bid in securing the national voter's document, they automatically become Gambians" (quoted in M'Bai 2004a).

A few days after this incident, I was meeting with a mid-level IEC official whom I shall refer to as Mr. Joof. Mr. Joof had worked for the IEC for close to a decade. Other Gambians I spoke to about the IEC saw him as competent and impartial. Although Mr. Joof kept his personal political views mostly to himself, he had once told me that he was unhappy with the ruling party, the Alliance for Patriotic Reorientation and Construction (APRC). Life in the Gambia was not easy if "you're not green," he had said, in reference to the party color of the APRC. At this meeting, we were sitting in his office in the IEC headquarters in Latrikunda, a town not too far from Banjul. I asked him if he had seen the newspaper reports of the incident and what he thought. After a moment's silence he leaned forward and excitedly responded:

Voting is the last [step of the democratic process], everything starts from registration. Everything starts from the acquisition of what? These national documents. That's something that people need to understand....If you look at the Gambia, the borders are porous in the sense that we are surrounded by Senegal. There are a lot of foreign nationals in the Gambia: Nigerians, Senegalese, Guineans...Mauritanians, they are all here. The thing is, people need to be educated better...This is where the problem lies, we don't issue birth certificates, we don't issue passports, we don't issue identity cards. If anybody comes with a valid document, we don't have to question them.

In the first instance, Mr. Joof's statement seems to do no more than confirm that the voter registration card is simply a normative technology of 
government wielded to circumscribe a Gambian national identity. But such an interpretation insufficiently captures what I describe as a feeling of beleaguerment traceable between the lines of both the newspaper report and Mr. Joof's statement. The notion of beleaguerment brings out a sense that people feel that their current conditions are threatened by what others may do and that they are unable to adequately defend themselves against these actions. This formulation resonates with that of the "uncanny," or an unrepresentable feeling of dread, in Gampel (2000). Unlike the uncanny, however, in my use of beleaguerment people are sustained in their apprehension by rumors and media reports as much as by individual experience. I also consider the notion to have a politico-legal (rather than psychological) quality where morally-laden issues such as immigration, for instance, necessarily interact with the institutional logics and laws of bureaucracies (Fassin 2005).

I hence use the term beleaguerment to emphasize that what is at issue in both the newspaper article and in Mr. Joof's statement that Nigerians, Senegalese and others can enter the Gambia almost willy-nilly is not simply hostility toward foreigners. The ease with which foreigners can enter the Gambia is well-established as the Casamance-Gambia border has a long history of porosity. Gambian authorities have traditionally welcomed Jola, the predominant ethnic group in the Casamance and the fourth largest one in the Gambia, to settle in the Gambia (Nugent 2007). The presence of Senegalese in the Gambia, as reported in the newspaper, is therefore not remarkable to any Gambian and is not the reason why this incident became a news item. The story became news on the basis of the threat posed by these particular foreigners to the integrity of a bureaucratic process. Had they been able to register, they would have illegitimately obtained a measure of say in Gambian domestic affairs and, by extension, become Gambian. Similarly, the substance of Mr. Joof's dismay is not that foreigners are present in the Gambia per se, but rather the inadequacy of peoples' understanding of the registration process from which, in his words, "everything" begins. This process, from the initial voter registration to voting and naturalization, is presented as highly routinized: with the acquisition of a valid document, subsequent steps become automatic and are not usually questioned. The automatic nature of a process that in this instance is fundamentally flawed-according to Gambian law, a foreigner cannot register to vote so the sequence implied in Mr. Joof's statement (voter registration first, then naturalization) upends how the process is expected to work normally-heightens some Gambians' feeling of beleaguerment. Once outsiders obtain registration it is difficult to stop them from becoming Gambian.

Both Mr. Joof's statement and the newspaper article bring out this notion of beleaguerment. The dismay expressed is less about the possibility that foreigners can enter the Gambia and more about their possible abuse of the 
voter registration process and, by extension, the democratic process. Since sociality, in part, consists of recognizing the validity and generalizability of the formal processes of a given group (Stinchcombe 2001), the anti-social nature of the Senegalese storming the IEC's registration post is strongly underlined. In this regard, the voter registration process is not simply about patrolling the boundaries of a Gambian subject, but also about demarcating a subject whose very sociality is contingent upon understanding and playing by a specific set of bureaucratic rules. The interactions and discussions around the card, thus, bring out a demarcation between 'good' foreigners who understand proper procedures and 'bad' foreigners who, like the Senegalese storming the IEC post, either do not understand or may subvert these procedures.

I will now turn briefly to rumors of a crime spree in the Banjul area to offer a useful analogy to the discussion of beleaguerment. At about the same time as the voter registration process, I heard rumors of crimes with varying degrees of supernatural involvement but with a common theme of absolute externality to the group. These crimes were the murder of a young girl, whose headless body was found behind a gas station, the murder of a security guard outside a residence in the posh suburb of Fajara, and reported incidents of "penis snatching" in the area. These acts are relevant to my discussion of beleaguerment and the Senegalese rush of the IEC registration station as both media reports and rumors swiftly reached the conclusion that these crimes were committed by foreigners (M'Bai 2004b). One taxi driver based next to a small boutique in the neighborhood where the murder of the security guard reportedly took place suggested to me that the blood of both the guard and the girl had been drained for human ritual consumption. When I asked him who was responsible, he suggested Nigerians, Sierra Leoneans, or people from the Casamance. One of Mr. Joof's colleagues similarly told me, after I asked him what he thought about the murders, that "Gambians would not do that [commit supernatural crimes]... These people are not Gambians. They are foreigners."

The idea that accusations of dark magic and criminality constitute a way to police the boundaries of the community, to enforce societal norms, and to give substance to communal fears is something of an anthropological mainstay (e.g. Bastian 1993, Geschiere 1997, Siegel 2006). I suggest that registration fraud and magic, while unconnected incidents, highlight in similar ways the vulnerability felt by the Gambians with whom I worked in the spring of 2004. During this period, both registration problems and supernatural crime were frequently discussed in the media as well as in everyday conversations. In a sense, Gambians like Mr. Joof (and Gambian political modernity) were doubly threatened, exposed to forces both mundane and supernatural. Siegel's (2006: 221-222) description of the witch as "an alterity which cannot be accepted" seems an apt paraphrase for the foreigners who fail to apprehend 
properly the voter registration process and thereby contribute to these Gambians' feeling of beleaguerment in which the bureaucratic procedures they believe in are on the verge of becoming undone. This discussion of attempted voter registration fraud and rumors of crime suggest that Gambian voter registration cards are not simply a Gambian government strategy to embrace its population and making it countable and verifiable. Beyond this governmentality lies a different concern. This vulnerability is concerned with more than the prevention of electoral cheating and is given shape as a sense of beleaguerment that is substantiated only through the attention paid to the voter registration process and the card itself.

\section{The Value of a Card: Identification and the IEC's Information Campaign}

I accordingly return to the voter registration card itself. Its back includes the warning that it lacks value to any person other than its owner. There are two related claims embedded in this warning: first, that the person depicted in the photograph and whose name and other information is on the card is actually the person in possession of the card and, second, that the card has no value outside of this restricted relationship. This value (and the lack thereof) is presented as a fait accompli; it is imbued with a taken-for-grantedness that is replicated across the documentary universe of the IEC. Recall, in this vein, Mr. Joof's statement that "if anybody comes with a valid document, we don't have to question them." The pronoun "we" here refers to the IEC, but can also be taken as indicative of the kind of person that properly understands the bureaucratic process of obtaining a card and other official identity documents. To the IEC, and to this person, that documents work, broadly speaking, is unquestionable. The risk that a voter registration card can be erroneously granted to a person is brushed aside as only possible if the document used to acquire the card was wrongly obtained, leaving the integrity of the IEC process intact. This attitude is by no means a cavalier one, but rather the consequence of a belief in the possibility of identifying a person with his or her identification document.

A brief conceptual discussion of the semiotic claims inherent in that belief is necessary. Value, Appadurai (1986) has suggested, is dependent upon a "regime of value." This regime is a set of social norms and practices that, shared in some measure between people, determine the value of an object. An object that is extricated from that regime has its value changed, diminished, or dissipated altogether. Following a semiotic approach to anthropology that insists that meaning inheres in "relations of relations" (Kockelman 2006: 83), apprehension of the regime itself - as in connoisseurship and the ability to 
spot a fake, for example - is itself a sign and a sort of social value. ${ }^{6}$ For this signification to take place, however, there must be a social framework - or a "semiotic ideology" in Keane's (2005) terminology - that allows an item to signify. The idea that identity documents identify an individual is thus not selfevident. Rather, such identification requires what Caplan (2001, cf. Groebner 2007) refers to as a "culture of identification" or what Derrida (2005: 56) describes as the modern ideal of "self-identification" of the subject of law with a "body of paper."

To suggest that an object is expressive of an identity-that a Gambian voter registration card signifies Gambian identity, for example-is, thus, to draw an incomplete picture. The meaning of the card is not limited to its denotational function in service of government. Additional questions that must be addressed to fully describe the card's significance include whether or not this connection between the card and the person is made, how this connection - when absent - can be achieved, and what the apprehension of this connection signifies in a person. This line of questioning continues the argument that the political significance of the card lies not only in its capacity to draw a distinction between Gambians and non-Gambians, but a distinction between those who 'get' that the card entails an on-paper extension of the self and those who do not understand this extension. Whereas in the previous section of this article, this distinction was drawn within a foreign population, here I suggest that the same distinction can be drawn among Gambians as well. Whether or not this distinction exists in actuality is not what matters; what matters is the perception, among middle-class Gambians and technocrats, that some Gambians do not apprehend the voter registration card properly.

The Gambia's IEC has shown an interest in promoting precisely such a proper apprehension of the voter registration card. In the lead-up to the 2001 presidential election, the IEC conducted-with the financial support of the United States Agency for International Development and the partnership of various local human rights and development groups-a public information campaign to instruct Gambians in proper registration and voting procedures. As part of the campaign, the IEC produced several posters to show Gambians the 'dos and don'ts' of the electoral process. During my visit to the IEC in 2004, these posters were on display in the IEC's resource room but they had been widely used during the 2001 election. One poster, for example, showed two men facing each other across a desk. A small briefcase bursts with cash on the desk. One of the men, dressed in a suit, holds a thick wad of bills in each hand and thrusts one of them toward the other man, dressed in a t-shirt and a skull cap of a kind common in the Gambia. The second man holds a voter registration card in one hand and fends off the man in the suit with the other hand. This poster caption reads: "Say no to bribery." A second poster depicts 
a Gambian holding up two voter registration cards, one in each hand. The card in his right hand is marked with a big red cross, and the poster is captioned "Do not register more than once." A third poster shows a man holding up a voter registration card while dropping a marble into a ballot drum (see n. 1). A stack of bills hovers over the drum and a red X marks them as an inappropriate or impermissible part of the voting process. The bubble above the man's head says "My vote is not for sale." A final poster similarly shows a man next to a ballot drum, but asking the imploring question: "I can vote, can you?"

These posters instruct the viewer to link inextricably the card, and only one card, to him or herself and to understand its non-transferability and lack of monetary value. They strive to imbue the viewer-members of the Gambian public - with a sense of responsibility, a sense of care, for the card and for the political process. In the final poster, in particular, this is to be accomplished through the identification of the material object (the voter registration card), the process (voting, or perhaps democracy tout court), and the person who, because of his participation in the emblematic act of voting and, by extension registering to vote, realizes his potential as a model political subject.

Equally important is that this identification (or relation) is a fragile one as seen in the worry, as manifested in the IEC posters, that bribery and other forms of corruption might influence the electoral process. This fragility, also implicit in Derrida's comment that a subject's self-identification with a document is an ideal one-and, hence, that this self-identification can be absent-underlines that the proper apprehension of the semiotic process of self-identification can fail or be absent. There is, thus, the perceived risk that some Gambians will fail to embody the desired political subjectivity that is able to show the requisite care for the voter registration card and the voter registration and voting processes. Just as in the earlier discussion of the Senegalese's failure to play by the rules and fraudulently try to obtain voter registration cards, the public education campaign suggests a subject that is not simply one of voting Gambian (or Gambian generally). Although the voter registration card as a particularly Gambian administrative practice is embedded in specifically Gambian discourses, it gives rise to a generic kind of subject with a particular way of caring for and paying attention to documentation. Below, I consider further how the political subject drawn out by the card is a generic one and not a specifically Gambian one.

\section{At the Station: Legalization and the Voter Registration Process}

The genericness of the subject rests in the distinction between those who understand a process and those who do not. This distinction implies an 
assessment of how the Gambia ought to work as a modern democracy and the extent to which Gambians are modern democratic subjects. Here, I accordingly consider how the card and associated processes allow people to render evident the Gambia's constitution as a modern, legitimate, democratic state and, as such, to render the political experiences of Gambians commensurable with the experiences of citizens of other countries. This commensuration opens up a space between the Gambia's current political conditions and an ideal imagined through an internationally circulating language of human rights and good governance. This language of human rights purports to be generic, which in turn enables Gambians to critique the political situation (cf. Weiss 2002). The use of this language accordingly confirms and validates the political subject of the card as a subject that is not simply a Gambian one but a generic one that could exist anywhere. To develop this argument, I consider an international legal case brought against the Gambia over the registration process and a report of the Commonwealth Observer Group to the 2001 presidential election before I return to the voter registration process.

In 1990, the small but influential Gambian political party People's Democratic Organization for Independence and Socialism (PDOIS) submitted a complaint to the African Commission on Human and Peoples' Rights - a pan-African human rights tribunal coincidentally based in the Gambia-alleging that flaws in the voter registration process constituted a violation of the principle of free and fair elections enshrined in Article 13 of the African Charter on Human and Peoples' Rights. ${ }^{7}$ Among the flaws identified by PDOIS was that would-be-registrants were not required to provide a street address. As a result, it was difficult to confirm that every single registration was valid and that there were no cases of multiple registrations. In response, the government argued that street addresses could not be required in a developing country such as the Gambia. When Jammeh took power in 1994, his government stated that the previous government's position was preposterous and accordingly changed the registration requirements so that these were more consistent with the PDOIS suggestions, and the African Commission deemed the complaint amicably resolved. In a conversation I later had with one of the author's of the complaint I was, nonetheless, told that despite changes to the electoral laws-including the establishment of the IEC-the electoral system was still possible to manipulate. ${ }^{8}$

The importance of this legal case for the present argument is not its outcome, however, but the presumption built into the very possibility of the case. Although a voter registration process might seem a purely domestic matter, the existence of international laws and institutions that take such processes under their purview shows its international resonance as well. ${ }^{9}$ 
Similarly, the very existence of the Commonwealth Observer Group's (2002) report indicates how the voter registration process-which really is about the appropriate mode of apprehending voter registration cards - is a matter of democratic credibility in both domestic and international eyes (Laakso 2002). However, the data here shows that this is a matter not simply of proper nationality but of a proper, modern political subjectivity-a subjectivity premised on there being an understanding of the voter registration card's capacity to index. The cards - and by extension the presence of subjects able to care for the cards appropriately - in a sense validates the Gambia as a modern nation-state or, analytically, a token of a type (cf. Navaro-Yashin 2003).

This process of validation is not an uncritical cookie cutter replication, through the enactment and verification of procedures such as voter registration, of a generic type (the nation state) in an African context. Although the human rights case and the report are internationally circulating ideas of what a state ought to be and the rationalities that it should promote, these ideas are also, in an almost recursive fashion, disseminated and shaped by African political actors (Chalfin 2006). These actors include political parties such as PDOIS, the complainant in the African Commission case. ${ }^{10}$ Thus, whereas the Gambian state in its present form may well not be "socially substantive" (Buckley 2005: 264) - not an entity with which one can have relationships-Gambians are acutely aware that this need not always be the case and that Gambian legality and democracy can, at least in theory, be improved through assiduous attention to the democratic process. ${ }^{11}$ As in Gordillo's (2006) study of the Toba and Wichí of Argentina, documents in the Gambia may thus offer a way to contest state power even if these documents are very much a function of the state

To support this point, I need to return to the voter registration process. My observation at voter registration stations also suggests that registering to vote is something that Gambians want to do, that it is taken seriously, and that the registration process is carefully guarded against corruption. A few days after my conversation with Mr. Joof, the two of us climbed into one of the IEC's white pick-up trucks to observe the registration process at three different stations scattered around Banjul. Due to space constraints, I will limit my discussion to the final station that was the busiest one and where we spent the most amount of time.

This station was located in the dusty courtyard of a combined police station and residential compound for the police officers. It was made up of a makeshift table and a couple of chairs under a tree. Several dusty cars and trucks were scattered throughout the courtyard, and small groups of children ran around playing games and chasing dogs. The official in charge of the station was an older gentleman who everyone referred to as "uncle." In addition to this man, there were two other IEC workers present and a 
policeman. Gambian electoral law permits all political parties to have observers during both registration and polling, and the ruling party and two of the opposition parties had sent representatives to this station. Despite the Gambia's tense political climate, there were no signs of animosity or jitters amongst the representatives. They were joking, sharing stories, and drinking attaya (a strong, sweet tea) with each other, and I was asked to take a picture of everyone posing smiling together. I obliged and one of the IEC officials laughed that they now had a "family picture" to commemorate the day.

During our visit, there were several instances where voter registration as a rule-bound process was put to the test. These incidents were important because they were occasions where the process could have been derailed, manipulated, or called into question by any of the party representatives. The fact that this did not happen is an indication of how invested the people present were in the procedure and their willingness to make sure it progressed without hiccups. I suggest that these incidents are evidence of the care that these Gambians felt for the political subjectivity signified by the voter registration card, a subjectivity marked precisely by its attention to process and apprehension of self-identification. In one instance, a young man came to the table holding a birth certificate in such poor shape that the text had been almost completely erased through wear. The IEC workers passed the birth certificate around, trying to make out the birth date. When the certificate got to Mr. Joof, he asked the man his birth date. The man responded November, 1986 (he did not give a day). This made him seventeen at the time but nineteen by the next scheduled presidential election in October 2006. He was turned away because, Mr. Joof later explained to me, the criterion is not whether the registrant is eighteen by the next presidential election but whether or not he or she is eighteen by the end of May of the current year. If the target date was the next regularly scheduled election and an unexpected election occurred-if a seat in the legislature became vacant because of a death, for example-he or she would be able to vote prematurely.

In a second instance, another young man was asked for his street address by the "uncle," the IEC official in charge of the station. The man replied "Tobacco Road," which, despite its name, is not a road but a district in Banjul. The man's too literal interpretation of Tobacco Road caused an intense but laughing conversation between the young man, the IEC officials, and the party observers. The man was prompted for a specific street name with questions of where he lived in relation to landmarks - such as a mosque and a local boutique-known to the other people at the station. After his street address had been thusly determined, he was registered according to procedure.

That the voter registration process is valued by Gambians comes out further in the following. During the supplementary drive (see n. 5) of spring of 
2004, some 7,000 individuals were added in Banjul alone to the registry of voters. While this might seem like a small number, considering that Banjul has an official population of only about 40,000 and that 7,000 registrants entailed an increase in the number of registered voters by $50 \%$, the number is in actuality quite impressive. It suggests a tremendous amount of interest, in the capital area at least, in the electoral process, and, presumably, a belief that the ability to vote matters. This suggestion is also borne out by voter turnout: in the 2001 presidential election, the IEC's official figures put the voter turnout at almost $90 \% .{ }^{12}$ Media coverage of registration and elections similarly emphasized their importance to the improvement of the Gambia. An editorial in the weekly newspaper Gambia News and Report concerning a local by-election, for example, referred to voting as an opportunity to "make a difference" and "take a decisive step" for the Gambia (Conateh 2004).

The above examples suggest that Gambians care deeply about the voting registration process, including the card, and want to invest it with a considerable amount of trust. This suggestion prompts a re-consideration of the fairly dystopian picture of the African state as "criminalized" (Bayart, Ellis and Hibou 1999) and "predatory" (Fatton 1992) to use two well known examples. When the literature on the African state considers it as manifested in social interactions, the emphasis tends to be on how various forms of authority (economic, legal, political, etc.) are pluralized and informalized (e.g. Mbembe 2001, 2005, Roitman 2004). Here, the role of documentary practices of the African state come off at best as ineffectual and at worst as a "regime of pretense" (Masquelier 2001: 269), with the real political, economic, and legal action happening elsewhere, behind the scenes. From this point of view, whatever importance documents might have once had has been diluted by corruption, predation, and informalization.

Autocracy and informalization are important in the Gambia-it would be hard to miss, for instance, the authoritarian element to Jammeh's rule and the existence of informal economic practices (Shipton 1995). Here I point, however, to another, in part countervailing, tendency. This is the tendency to formalize, legalize, and materialize the postcolonial African state. This latter drive was reinvigorated with the re-democratization of the continent in the 1990s - and accompanying phenomena like election monitoring, human rights reporting, and administrative commissions of inquiry-and the global turn toward neoliberal management strategies in economic and political life. ${ }^{13}$ These developments of neoliberalism and human rights are of an indisputable international provenance and claim to be generic. The tendency toward legalization and formalization is not, however, driven only by such macro level phenomena but also by the actions of Gambians who stand in line to register to vote or volunteer to scrutinize the process. In the context of this latter tendency, matters such as the voter registration card are a way to materialize the promise of a more stable and just state even if that materialization, linked 
to the state as it is, ultimately challenges the state as in the case of PDOIS complaint. ${ }^{14}$ This tendency, moreover, helps explain the dismay over a few Senegalese rushing a registration booth as discussed above. They were not just trying to cheat, or become Gambians, but were threatening the integrity of a procedure and thereby showing their incompatibility with the kind of political order implicit in the voter registration card. They were, thus, also threatening to derail the imperfect process of legalization and materialization in which Gambians like Mr. Joof have so much invested.

\section{Conclusion}

In sum, I have argued that the Gambian voter registration card marks two different kinds of membership. The first one is that of belonging in a national community, circumscribed by the legal requirements for eligibility to register. From this point of view, the voter registration card is no different from a passport, birth certificate, or other identity document. The voter registration card signals to a Gambian that he or she is a citizen, that he or she is entitled to the rights and obligations accruing to that status, and most significantly that he or she has the right to a modicum of say in national politics via elections. This membership tells only part of the story, however, as it occludes that which is not denotationally explicit in the card itself as well as incompletely explains what I have termed a feeling of beleaguerment-or an anxiety over the influence of others that is exacerbated by the perceived inadequacy of bureaucratic procedures - in the Gambia.

I have also argued for a second form of membership or identity. This is a more ephemeral one, only visible in the wider semiotic context of the card. It is not simply a membership in the national community, but what may be thought of as a generic political subject characterized by its ability to recognize and care for the validity and value of the voter registration card and the registration process. The card draws a distinction between a modern political subject who properly apprehends and cares for the voter registration process and a subject who does not. Even though this distinction can only be expressed as a function of the nation-state - through state-bound bureaucratic processes such as voter registration-it is a distinction that does not map neatly onto the divide between Gambians and foreigners. Rather, this distinction can include and exclude persons from both categories: the Senegalese who stormed the IEC post are in a sense analogous to the unidentified Gambians who need to be informed, through the IEC public awareness campaign, of proper care of the card. Both of these groups stand in contradistinction to people like Mr. Joof, the PDOIS complainants, and the workers at the registration station who claim to value the card and its related processes appropriately. 
In developing this more expansive subject out of the Gambian voter registration card, I have relied on recent anthropological work that eschews reading documents as simply classificatory devices of statecraft to develop the argument that documents occupy a particular place in Gambian politics and, by extension, African politics generally. While the African state is often characterized as being corrupt, incompetent, and liable to fail, and its documents as being simply pretense, fraudulent, or maybe at best a vain attempt to forestall the inevitable, my discussion of Gambian voter registration suggests an alternative. In the context of the late $20^{\text {th }}$ and early $21^{\text {st }}$ century emphasis on democracy and human rights - represented in this article by the report on the monitoring of a Gambian election and an international legal case-documents like voter registration cards are repositories of all the hope and improvement the language of human rights claims to bring about. The use of this language with its emphasis on a generic state form in the context of the voter registration process confirms the generic nature of the subjectivity implied by the card.

The voter registration card and associated processes bring into focus the possibility for Gambians to compare their present political and legal situation to an ideal imagined through the language of rights and free and fair elections. Even if the rule of law in the Gambia is troubled, the voter registration card is, to Gambians like Mr. Joof, profoundly important as the materialization of an internationally observed commitment by the state to behave in a certain fashion and as a way to render the experiences of Gambians commensurable with the experiences of citizens of other countries. At the same time, the voter registration card demands a commitment by Gambians to value the card and by extension the political process of affirmation and renewal through elections. Recognition of this commitment only strengthens the distinction between those who fail to grasp the significance of the nitty-gritty of the registration process, the voter registration card as an extension of the self, and those who appreciate the linkage between the card and the self and the centrality of bureaucratic processes to the constitution of a modern Gambia. For this latter group, to have trust in the card is simultaneously to uphold their own modern political subjectivity and to give substance to their hope for a future in which Gambia is not threatened by those who do not value the card or its procedures.

\section{Acknowledgements}

An early version of this article was presented at the American Anthropological Association meetings in Washington DC in 2007. I thank Kregg Heatherington and Leticia Barrera for inviting me to participate and Alexander Smith for his commentary. I am grateful to Narmala Halstead and the JLA's reviewers for prompting me to hone and considerably clarify the argument. Research in the 
Gambia was funded by the Law and Social Science Program of the National Science Foundation (Award ID 0318305). Any errors of fact or analysis are my responsibility.

\section{Biographical Note}

Niklas Hultin is Visiting Assistant Professor of Anthropology at Swarthmore College, USA. He holds a PhD in anthropology from the University of Pennsylvania and an LLM in human rights law from Queen's University Belfast. $\mathrm{He}$ has done research in the Gambia, Nigeria, and Senegal and published on the anthropology of human rights issues such as freedom of speech and children's rights in the Gambia.

\section{Notes}

${ }^{1}$ Gambians vote by dropping a marble into a spigot-like extension at the top of the drum of the political party for which they wish to vote. The drums are color coded by party as well as decorated with the party symbol or photograph of the candidate. The voter drops the marble-handed to him or her before entering the voting booth-into the hole and as the marble falls down the extension it hits a small bell, telling the election officials that a vote has been cast and that the marble will not be smuggled to a different constituency (when counting votes, officials count the number of marbles for each candidate in each constituency). This system is essentially the same one devised by the British during the colonial era. A photograph of a drum is included in Rice (1967). See also Wiseman (1979) for a more detailed description of these drums.

${ }^{2}$ My argument thus echoes the Comaroff's recent argument that South African crime statistics "fill the space between the unknowable and the axiomatic" (Comaroff and Comaroff 2006: 38) with the difference that I am concerned with how official documents like voter registration cards are used specifically to imagine an improvement in terms of human rights and democracy.

${ }^{3}$ It would thus be a mistake to consider Reed's argument as simply a documentary restatement of the well-worn, if felicitous, idea of mimesis as a form of "sympathetic magic" according to which mimicry leads to the appropriation of power and from there a form of resistance or critique (Taussig 1993: 38). While the documents with which Reed is concerned-the "warrant covers," produced by the prison bureaucracy, and "autographs" produced by the inmates-share a common form and allow for the filling in of pertinent information, the autographs do not mimic the former as much as they draw upon a similar understanding of the documents as actors. See also Gordillo (2006), who is similarly skeptical of a single-minded focus on the denotation and material aspect of identification papers.

${ }^{4}$ For more information on the political and human rights situation of the Gambia, see, for example, Hultin (2007), Saine (2002), and Wiseman (1996).

${ }^{5}$ In the Gambia, general registration drives are conducted in the lead-up to elections. The IEC conducts supplementary registrations every two or three years to catch individuals who were not eighteen (the voting age), ill or otherwise unable to register, or resided out of the country during the general registration. It is possible to register to vote only during 
these drives, although one can transfer one's registration from one constituency to another or apply for a replacement card (in case of loss) at any time.

${ }^{6}$ The anthropological literature on the perception of value as an element of social status and determinative of social relations is voluminous. See, for example, Jamieson (1999) and Patico (2005).

${ }^{7}$ Communication 44/90, PDOIS v. the Gambia, African Commission on Human and People's Rights.

${ }^{8}$ Interview, Halifa Sallah, January 30, 2004.

${ }^{9}$ There is a considerable literature of the re-calibration of sovereignty as a result of sinternational human rights law. See, for example, Reus-Smit (2001).

${ }^{10}$ This is especially true of the Gambia which, as the seat of the African Commission, has historically associated itself with the international human rights agenda and its definition of what amounts to proper statecraft.

${ }^{11}$ There is an element of self-flagellation to this awareness. During 2004, there were media reports of a paper shortage preventing the issuing of national identity cards. While these reports were occasionally interpreted as evidence of election fraud, they were also cast in a self-deprecatory light to underscore the inadequacy of the Gambia's present economic and political situation (Darboe 2004).

${ }^{12}$ Official election statistics available at $\mathrm{http}: / / \mathrm{www} . i e c . g m / \operatorname{artman} /$ publish/cat_index_40 shtml.

${ }^{13}$ For an anthropological account of these processes, see, for example, Englund (2006). Note, however, that while I share Englund's disquiet with the uncritical replication of ideas of human rights in African contexts, my purpose herein is the much more limited one of situating the voter registration card and similar documents in this process.

${ }^{14}$ A parallel argument is brought forth by Karlström (2003), who criticizes Mbembe for overlooking the potential for criticism and the recovery of an oppositional voice in the dramaturgy of African politics.

\section{References}

Appadurai, Arjun (1986) 'Introduction: Commodities and the Politics of Value', in A. Appadurai (ed.) The Social Life of Things: Commodities in Cultural Perspective, pp. 3-63. New York: Cambridge University Press.

Bastian, Misty L. (1993) “ "Bloodhounds Who Have No Friends": Witchcraft and Locality in the Nigerian Political Press', in J. Comaroff and J. Comaroff (eds.) Modernity and Its Malcontents: Ritual and Power in Postcolonial Africa, pp. 129-166. Chicago, IL: University of Chicago Press.

Bayart, Jean-Francois, Stephen Ellis and Beatrice Hibou (1999) The

Criminalization of the State in Africa. Bloomington: Indiana University Press.

Buckley, Liam (2005) 'Objects of Love and Decay: Colonial Photographs in a Postcolonial Archive', Cultual Anthropology (20): 249-270.

Caplan, Jane (2001) “"This or That Particular Person”: Protocols of Identification in Nineteenth-Century Europe', in J. Caplan and J. Torpey (eds.) Documenting Individual Identity: The Development of State Practices in the Modern World, pp. 49-66. Princeton, NJ: Princeton University Press. 
Chalfin, Brenda (2006) 'Global Customs Regimes and the Traffic in Sovereignty: Enlarging the Anthropology of the State', Current Anthropology (47): 243-276.

Comaroff, Jean and John Comaroff (2006) An Excursion into the Criminal Anthropology of the Brave Neo South Africa. Münster, Germany: Lit Verlag.

Commonwealth Observer Group (2002) The Gambia Presidential Election, 18 October 21. London: Commonwealth Secretariat.

Conateh, Swaebou (2004) 'Why Jarra West Is Important in Our Politics', the Gambia News and Report Magazine (Banjul), June 22-28, pp. 12.

Darboe, Ousman (2004) 'ID Card Scarcity Hits Immigration', Daily Observer (Banjul), April 30, pp. 1-2.

Derrida, Jacques (2005) Paper Machine. Stanford, CA: Stanford University Press.

Englund, Harri (2006) Prisoners of Freedom: Human Rights and the African Poor. Berkeley: University of California Press.

Fassin, Didier (2005) 'Compassion and Repression: The Moral Economy of Immigration Policies in France', Cultural Anthropology (20): 362-387.

Fatton, Robert (1992) Predatory Rule: State and Civil Society in Africa. Boulder, CO: Lynne Rienner.

Ferguson, James (2005) 'Seeing Like an Oil Company: Space, Security, and Global Capital in Neoliberal Africa', American Anthropologist (107): 377382.

Ferguson, James and Akhil Gupta (2002) 'Spatializing States: Toward an Ethnography of Neoliberal Governmentality', American Ethnologist (29): 981-1002.

Foucault, Michel (1991) 'Governmentality,' in G. Burchell, C. Gordon and P. Miller (eds.) The Foucault Effect: Studies in Governmentality, pp. 87-104. Chicago, IL: University of Chicago Press.

Foucault, Michel (1995) Discipline and Punish: The Birth of the Prison. New York: Vintage.

Gampel, Yolanda (2000) 'Reflections on the Prevalence of the Uncanny in Social Violence', in A. C. G. M. Robben and M. M. Suárez-Orozco (eds.) Cultures under Siege: Collective Violence and Trauma, pp. 48-69. New York: Cambridge University Press.

Geschiere, Peter (1997) The Modernity of Witchcraft: Politics and the Occult in Postcolonial Africa. Charlottesville: University of Virginia Press.

Gordillo, Gastón (2006) 'The Crucible of Citizenship: ID-Paper Fetishism in the Argentinean Chaco', American Ethnologist (33): 162-176.

Groebner, Valentin (2007) Who Are You? Identification, Deception, and Surveillance in Early Modern Europe. New York: Zone Books.

Hultin, Niklas (2007) "Pure Fabrication”: Information Policy, Media Rights, and the Postcolonial Public', PoLAR: Political and Legal Anthropology Review (30): 1-21. 
Jamieson, Mark (1999) 'The Place of Counterfeits in Regimes of Value: An Anthropological Approach', Journal of the Royal Anthropological Institute (n.s.) (5): 1-11.

Karlström, Mikael (2003) 'On the Aesthetics and Dialogics of Power in the

Postcolony', Africa: Journal of the International African Institute (73): 5776.

Keane, Webb (2005) 'Signs Are Not the Garb of Meaning: On the Social Analysis of Material Things', in D. Miller (ed.) Materiality pp. 182-205. Durham, NC: Duke University Press.

Kockelman, Paul (2006) 'A Semiotic Ontology of the Commodity', Journal of Linguistic Anthropology (16): 76-102.

Laakso, Liisa (2002) 'The Politics of International Election Observation: The Case of Zimbabwe in 2000', Journal of Modern African Studies (40): 437464.

M'Bai, Pa Nderry (2004a) 'Casamance Natives Storm Registration Centres, IEC Rejects Their Applications', The Point (Banjul), April 30, p. 3.

M'Bai, Pa Nderry (2004b) 'The Weekend's Gruesome Murders: Police Explain', The Point (Banjul), May 3, p. 3.

Masquelier, Adeline (2001) 'Behind the Dispensary's Prosperous Façade: Imagining the State in Rural Niger', Public Culture (13): 267-291.

Mbembe, Achille (2001) On the Postcolony. Berkeley: University of California Press.

Mbembe, Achille (2005) 'Sovereignty as a Form of Expenditure', in T. B. Hansen and F. Stepputat (eds.) Sovereign Bodies: Citizens, Migrants, and States in the Postcolonial World, pp. 148-166. Princeton, NJ: Princeton University Press.

Mitchell, Timothy (1991) 'The Limits of the State: Beyond Statist Approaches and Their Critics', The American Political Science Review (85): 77-96.

Miyazaki, Hirokazu (2006) The Method of Hope: Anthropology, Philosophy, and Fijian Knowledge. Stanford, CA: Stanford University Press.

Navaro-Yashin, Yael (2003) 'Legal/Illegal Counterpoints: Subjecthood and

Subjectivity in an Unrecognized State', in R. A. Wilson and J. P. Mitchell (eds.) Human Rights in Global Perspective: Anthropological Studies of Rights, Claims and Entitlements, pp. 71-92. London: Routledge.

Nugent, Paul (2007) 'Cyclical History in the Gambia/Casamance Borderlands:

Refuge, Settlement and Islam from c. 1880 to the Present', Journal of African History (48): 221-243.

Osborne, Thomas (1994) 'Bureaucracy as a Vocation: Governmentality and Administration in Nineteenth-Century Britain', Journal of Historical Sociology (7): 289-313.

Patico, Jennifer (2005) 'To Be Happy in a Mercedes: Tropes of Value and Ambivalent Visions of Marketization', American Ethnologist (32): 479-496.

Reed, Adam (2006) 'Documents Unfolding', in A. Riles (ed.) Documents: Artifacts of Modern Knowledge, pp. 158-176. Ann Arbor: University of Michigan Press. 
Reus-Smit, Christian (2001) 'Human Rights and the Social Construction of Sovereignty', Review of International Studies (27): 519-538.

Rice, Berkeley (1967) Enter Gambia: The Birth of an Improbable Nation. Boston, MA: Houghton Mifflin.

Riles, Annelise (2001) The Network inside Out. Ann Arbor: University of Michigan Press.

Riles, Annelise, ed. (2006a) Documents: Artifacts of Modern Knowledge. Ann Arbor: University of Michigan Press.

Riles, Annelise (2006b) 'Introduction: In Response', in A. Riles (ed.)

Documents: Artifacts of Modern Knowledge, pp. 1-40. Ann Arbor: University of Michigan Press.

Roitman, Janet (2004) Fiscal Disobedience: An Anthropology of Economic Regulation in Central Africa. Princeton, NJ: Princeton University Press.

Saine, Abdoulaye (2002) 'Post-Coup Politics in the Gambia', Journal of Democracy (13): 167-172.

Shipton, Parker (1995) 'How Gambians Save: Culture and Economic Strategy at an Ethnic Crossroads', in J. I. Guyer (ed.) Money Matters: Instability, Values, and Social Payments in the Modern History of West African Communities, pp. 245-276. Oxford: James Currey.

Siegel, James (2006) Naming the Witch. Stanford, CA: Stanford University Press.

Silverstein, Michael and Greg Urban, eds. (1996) Natural Histories of

Discourse. Chicago, IL: University of Chicago Press.

Stinchcombe, Arthur L. (2001) When Formality Works: Authority and Abstraction in Law and Organizations. Chicago, IL: University of Chicago Press.

Sztompka, Piotr (1999) Trust: A Sociological Theory. New York: Cambridge University Press.

Taussig, Michael T. (1993) Mimesis and Alterity: A Particular History of the Senses. New York: Routledge.

Torpey, John C. (2000) The Invention of the Passport: Surveillance, Citizenship, and the State. Cambridge: Cambridge University Press.

Weiss, Brad (2002) 'Thug Realism: Inhabiting Fantasy in Urban Tanzania', Cultural Anthropology (17): 93-124.

West, Harry G. (2003) “"Who Rules Us Now?” Identity Tokens, Sorcery, and Other Metaphors in the 1994 Mozambican Elections', in H. G. West and T. Sanders (eds.) Transparency and Conspiracy: Ethnographies of Suspicion in the New World Order, pp. 92-124. Durham, NC: Duke University Press.

Wiseman, John A. (1979) 'Local Elections in the Gambia: Where the Marble Rings the Bell', Round Table (275): 232-237.

Wiseman, John A. (1996) 'Military Rule in the Gambia: An Interim Assessment', Third World Quarterly (17): 917-940.

Yngvesson, Barbara and Susan Bibler Coutin (2006) 'Backed by Papers: Undoing Persons, Histories, and Return', American Ethnologist (33): 177190. 


\author{
Niklas Hultin \\ Visting Assistant Professor \\ Department of Sociology and Anthropology \\ Swarthmore College, Swathmore, PA 19081, USA \\ Email:nhultin1@swartmore.edu
}

